Review

International Journal of Biological Sciences

ISSN 1449-2288 www.biolsci.org 2008 4(6):406-414

(C) Ivyspring International Publisher. All rights reserved

\title{
Genome Assembly Anchored QTL Map of Bovine Chromosome 14
}

\section{Tito A. Wibowo ${ }^{1}$, Charles T. Gaskins ${ }^{1}$, Ruth C. Newberry ${ }^{1}$, Gary H. Thorgaard ${ }^{2}$, Jennifer J. Michal ${ }^{1}$ and Zhihua Jiang ${ }^{1 凶}$}

1. Department of Animal Sciences, Washington State University, Pullman, WA 99164-6351, USA

2. School of Biological Sciences, Washington State University, Pullman, WA 99164-4236, USA.

$\triangle$ Correspondence to: Zhihua Jiang, Tel: +509 335 8761; Fax: +509 335 4246; E-mail: jiangz@wsu.edu

Received: 2008.11.08; Accepted: 2008.11.11; Published: 2008.11.12

Bovine chromosome 14 (BTA14) has been widely explored for quantitative trait loci (QTL) and genes related to economically important traits in both dairy and beef cattle. We reviewed more than 40 investigations and anchored 126 QTL to the current genome assembly (Btau 4_0). Using this anchored QTL map, we observed that, in dairy cattle, the region spanning $0-10 \mathrm{Mb}$ on BTA14 has the highest density QTL map with a total of 56 QTL, mainly for milk production traits. It is very likely that both somatic cell score (SCS) and clinical mastitis share some common QTL in two regions: $61.48 \mathrm{Mb}-73.84 \mathrm{Mb}$ and $7.86 \mathrm{Mb}-39.55 \mathrm{Mb}$, respectively. As well, both ovulation rate and twinning rate might share a common QTL region from $34.16 \mathrm{Mb}$ to $65.38 \mathrm{Mb}$. However, there are no common QTL locations in three pregnancy related phenotypes: non-return rate, pregnancy rate and daughter pregnancy rate. In beef cattle, the majority of QTL are located in a broad region of $15 \mathrm{Mb}-45 \mathrm{Mb}$ on the chromosome. Functional genes, such as CRH, CYP11B1, DGAT1, FABP4 and TG, as potential candidates for some of these QTL, were also reviewed. Therefore, our review provides a standardized QTL map anchored within the current genome assembly, which would enhance the process of selecting positional and physiological candidate genes for many important traits in cattle.

Key words: cattle, BTA14, QTL, review

\section{Introduction}

Livestock species, especially cattle, play an important role in economic development worldwide [1]. To increase profitability, cattle with superior, economically important traits such as growth, milk production and meat quality, have been selected and used as breeding stock. Traditionally, phenotypic and pedigree data have been used to select and pair the best sires and dams, which would in many cases result in offspring with improved phenotype values compared to the previous generation. This simple method of data collection and selection tripled U.S. milk production from 1940-1991 with fewer cows [2]. Therefore, any sophisticated techniques to choose sires and dams that are genetically superior will further enhance the process, leading to further improvement and economical gain.

Finding genes responsible for these economically important traits, however, is challenging because they are quantitative traits in nature [3,4]. In other words, these traits are polygenic and are controlled by the accumulative action of many Mendelian genes. Moreover, the number of genes involved is unknown, and environmental factors can also complicate the process because they can have a confounding effect on phenotypes [3, 4, 5, 6]. Nonetheless, recent developments in molecular biology and statistical methodologies allow the possibility to localize regions/genes in the genome or chromosome that are responsible for traits of interest $[7,8,9]$.

To date, bovine chromosome 14 (BTA14) has been one of the most widely studied chromosomes for quantitative trait loci (QTL) related to many economically important traits in cattle [10]. There are more than 40 investigations dealing with QTL or genes for various traits, reporting a total of 126 QTL spanning this chromosome alone. In the present review, we surveyed QTL or genes on BTA14 discovered in both dairy and beef cattle. Since many of these studies used different sets of markers, mostly microsatellites, we integrated them into the current genome assembly (Btau 4_0) (http://www.ncbi.nlm.nih.gov/projects/ genome/guide/cow/) in order to standardize QTL locations. Such a genome assembly anchored QTL map provides the best view on QTL density for each phenotype and the potential links between QTL and functional genes for future study. 


\section{QTL detected on BTA14 in dairy cattle}

In dairy cattle, the majority of QTL mapping on BTA14 are related to milk production traits, such as milk yield (MY), fat percentage (FP) or fat content, fat yield (FY), protein percentage (PP) or protein content and protein yield (PY) $[2,4,5,6,11,12,13,14,15,16$, $17,18,19,20,21,22,23,24,25]$. Other traits, such as reproduction (REPRO) (calving ease, CE; daughter pregnancy rate, DPR; non return rate, NRR; ovulation rate, OVR; pregnancy rate, PR and twinning, TWIN)
$[2,18,23,26,27]$, health (somatic cell score, SCS, and clinical mastitis, CLM) $[18,21,25,28,29,30]$ and udder related traits (URT) (fore udder attachment, FUA; front teat placement, FTP; rear udder width, RUW and udder somatic cell score, USCS) $[2,4,23]$ were also investigated on BTA14. References, significance levels ( $p$ values or $\mathrm{F}$ values), peak or flanking marker(s), genome-anchored locations (in $\mathrm{Mb}$ ), and linkage map locations (in $\mathrm{cM}$ ) for each of these QTL are listed in Table 1.

Table 1. QTL reported on BTA14 for milk production traits in dairy cattle.

\begin{tabular}{|c|c|c|c|c|}
\hline Reference & P or $F^{*}$ value & Markers & $\mathbf{M b}$ & $\mathbf{c M}$ \\
\hline \multicolumn{5}{|c|}{ FAT PERCENTAGE (FP) (or FAT CONTENT) } \\
\hline Ashwell et al. 1997 & 0.0181 & BM302 & 33.62 & 52.37 \\
\hline Ashwell et al. 2002 & 0.001 & BMS1678 & 9.19 & 14.01 \\
\hline Ashwell et al. 2002 & 0.073 & BMS1678 & 9.19 & 14.01 \\
\hline Ashwell et al. 2002 & $<0.0001$ & BMS1678 & 9.19 & 14.01 \\
\hline Ashwell et al. 2004 & $23.1^{*}$ & ILSTS039-BMS1678 & $1.20-9.19$ & $0-14.01$ \\
\hline Bennewitz et al. 2003 & $<0.01$ & KIEL_E8 & 0.26 & 0 \\
\hline Bennewitz et al. 2003 & $<0.01$ & KIEL_E8-RM180 & $0.26-17.16$ & $0-33.31$ \\
\hline Bennewitz et al. 2004 & $<0.001$ & DGAT1 & 0.44 & 18.70 \\
\hline Boichard et al. 2003 & $<0.001$ & CSSM066 & 3.81 & 5.13 \\
\hline Boichard et al. 2003 & 0.0004 & CSSM066 & 3.81 & 5.13 \\
\hline Boichard et al. 2003 & 0.11 & CSSM066 & 3.81 & 5.13 \\
\hline Heyen et al. 1999 & 0.0023 & BM1508 & 8.27 & 17.85 \\
\hline Heyen et al. 1999 & $<0.00001$ & ILSTS039 & 1.2 & 0 \\
\hline Kaupe et al. 2007 & $<0.001$ & CYP11B1 & 1.29 & 29.80 \\
\hline Kaupe et al. 2007 & $<0.001$ & DGAT1 & 0.44 & 18.70 \\
\hline Kuhn et al. 2004 & $<0.0001$ & CSSM066-ILSTS039 & $1.20-3.81$ & $0-5.13$ \\
\hline Rodriguez-Zas et al. 2002 & & ILSTS039 & 1.2 & 0 \\
\hline Ron et al. 1999 & 0.0003 & CSSM066 & 3.81 & 5.13 \\
\hline Thaller et al. 2003 & $<0.001$ & CSSM066-ILSTS039 & $1.20-3.81$ & $0-5.13$ \\
\hline Viitala et al. 2003 & $<0.0029$ & ILSTS039-BMS1747 & $1.20-7.87$ & $0-10.50$ \\
\hline Zhang et al. 1998 & & ILSTS011-BM302 & $11.78-33.62$ & $25.71-52.37$ \\
\hline \multicolumn{5}{|c|}{ FAT YIELD (FY) } \\
\hline Ashwell et al. 2002 & $<0.0001$ & BMS1678 & 9.19 & 14.01 \\
\hline Ashwell et al. 2004 & $12.1^{*}$ & ILSTS039-BMS1678 & $1.20-9.19$ & $0-14.01$ \\
\hline Ashwell et al. 2004 & $10.5^{*}$ & BMS1941-BM8215 & $24.67-27.34$ & $41.71-48.23$ \\
\hline Bennewitz et al. 2003 & $<0.01$ & KIEL_E8-CSSM066 & $0.26-3.81$ & 5.13 \\
\hline Bennewitz et al. 2003 & $<0.01$ & KIEL_E8-CSSM066 & $0.26-3.81$ & 5.13 \\
\hline Bennewitz et al. 2003 & $<0.01$ & KIEL_E8 & 0.26 & 0 \\
\hline Bennewitz et al. 2004 & $<0.01$ & DGAT1 & 0.44 & 18.70 \\
\hline Boichard et al. 2003 & 0.0011 & CSSM066 & 3.81 & 5.13 \\
\hline Harder et al. 2006 & 0.01 & BM4513-BL1036 & $61.48-76.75$ & 79.79-100.16 \\
\hline Heyen et al. 1999 & 0.0005 & CSSM066 & 3.81 & 5.13 \\
\hline Heyen et al. 1999 & 0.00002 & ILSTS039 & 1.2 & 0 \\
\hline Kaupe et al. 2007 & $<0.001$ & CYP11B1 & 1.29 & 29.80 \\
\hline Looft et al. 2001 & $<0.01$ & ILSTS039-CSSM066 & $1.20-3.81$ & $0-5.13$ \\
\hline Thaller et al. 2003 & $<0.001$ & ILSTS039-CSSM066 & $1.20-3.81$ & $0-5.13$ \\
\hline Viitala et al. 2003 & 0.0398 & ILSTS039-BMS1747 & $1.20-7.87$ & $0-10.50$ \\
\hline Winter et al. 1998 & $<0.0001$ & ILSTS039-BM1508 & $1.20-8.27$ & $0-17.85$ \\
\hline Zhang et al. 1998 & $2.25^{*}$ & ILSTS011-BM302 & $11.78-33.62$ & 25.71-52.37 \\
\hline
\end{tabular}




\begin{tabular}{|c|c|c|c|c|}
\hline \multicolumn{5}{|c|}{ MILK YIELD (MY) } \\
\hline Ashwell et al. 1997 & 0.0302 & BM302 & 33.62 & 52.37 \\
\hline Bagnato et al. 2008 & 0.0501 & CSSM066 & 3.81 & 5.13 \\
\hline Bagnato et al. 2008 & 0.0485 & BMS1747 & 7.87 & 10.5 \\
\hline Bagnato et al. 2008 & 0.00148 & BMS947 & 51.274 & 69.8 \\
\hline Bagnato et al. 2008 & 0.000311 & BL1036 & 76.75 & 100 \\
\hline Bennewitz et al. 2003 & $<0.01$ & KIEL_E8 & 0.26 & 0 \\
\hline Bennewitz et al. 2003 & $<0.01$ & KIEL_E8-CSSM066 & $0.26-3.81$ & 5.13 \\
\hline Boichard et al. 2003 & 0.02 & CSSM066 & 3.81 & 5.13 \\
\hline Boichard et al. 2003 & 0.0002 & CSSM066 & 3.81 & 5.13 \\
\hline Herder et al. 2006 & $<0.01$ & KIEL_EB-CSSM066 & $0.26-3.81$ & 5.13 \\
\hline Heyen et al. 1999 & 0.0052 & BM4305 & 65.03 & 83.31 \\
\hline Kaupe et al. 2007 & $<0.01$ & CYP11B1 & 1.29 & 29.80 \\
\hline Kaupe et al. 2007 & $<0.001$ & DGAT1 & 0.44 & 18.70 \\
\hline Looft et al. 2001 & $<0.01$ & ILSTS039-CSSM066 & $1.20-3.81$ & $0-5.13$ \\
\hline Rodriguez-Zas et al. 2002 & & CSSM066 & 3.81 & 5.13 \\
\hline Schnabel et al. 2005 & $16.32^{*}$ & BMC1207-BMS1899 & $34.16-51.17$ & 51.94-69.01 \\
\hline Thaller et al. 2003 & $<0.001$ & CSSM066-ILSTS039 & $1.20-3.81$ & $0-5.13$ \\
\hline \multicolumn{5}{|c|}{ PROTEIN PERCENTAGE (PP) (or PROTEIN CONTENT) } \\
\hline Ashewell et al. 2004 & $9.5^{*}$ & BMS1678-ILSTS011 & $9.19-11.78$ & $14.01-25.71$ \\
\hline Bagnato et al. 2008 & 0.014 & ILSTS039 & 1.20 & 0 \\
\hline Bagnato et al. 2008 & 0.0045 & CSSM066 & 3.81 & 5.13 \\
\hline Bagnato et al. 2008 & 0.015 & DIK2201 & 6.378 & 8.1 \\
\hline Bagnato et al. 2008 & 0.012 & BMS2055 & 74.473 & 93.7 \\
\hline Bennewitz et al. 2004 & $<0.001$ & DGAT1 & 0.44 & 18.70 \\
\hline Boichard et al. 2003 & $<0.001$ & CSSM066 & 3.81 & 5.13 \\
\hline Boichard et al. 2003 & $<0.00001$ & CSSM066 & 3.81 & 5.13 \\
\hline Heyen et al. 1999 & 0.0048 & ILSTS039 & 1.2 & 0 \\
\hline Kaupe et al. 2007 & $<0.001$ & CYP11B1 & 1.29 & 29.80 \\
\hline Mosiq et al. 2001 & $<0.01$ & BM6425 & 73.84 & 95.14 \\
\hline Rodriguez-Zas et al. 2002 & & BM6425 & 73.84 & 95.14 \\
\hline Schnabel et al. 2005 & & BMC1207-BMS1899 & $34.16-51.17$ & $51.94-69.01$ \\
\hline Thaller et al. 2003 & $<0.001$ & ILSTS039-CSSM066 & $1.20-3.81$ & $0-5.13$ \\
\hline Viitala et al. 2003 & $<0.0029$ & BMS1747-BMS740 & $7.87-39.55$ & $10.50-60.69$ \\
\hline Bennewitz et al. 2003 & $<0.01$ & RM180-CSSM066 & 3.81 & $5.13-35.31$ \\
\hline Bennewitz et al. 2003 & $<0.01$ & KIEL_E8 & 0.26 & 0 \\
\hline Kaupe et al. 2007 & $<0.001$ & DGAT1 & 0.44 & 18.70 \\
\hline Kaupe et al. 2007 & $<0.001$ & CYP11B1 & 1.29 & 29.80 \\
\hline \multicolumn{5}{|c|}{ PROTEIN YIELD (PY) } \\
\hline Ashwell et al. 2002 & 0.0005 & BM6425 & 73.84 & 95.14 \\
\hline Ashwell et al. 2004 & 14.7 & BM4305-INRA100 & $65.03-75.88$ & 83.31 \\
\hline Bennewitz et al. 2003 & $<0.01$ & KIEL_E8 & 0.26 & 0 \\
\hline Kaupe et al. 2007 & $<0.001$ & DGAT1 & 0.44 & 18.70 \\
\hline Looft et al. 2001 & $<0.01$ & ILSTS039-CSSM066 & $1.20-3.81$ & $0-5.13$ \\
\hline Thaller et al. 2003 & $<0.01$ & ILSTS039-CSSM066 & $1.20-3.81$ & $0-5.13$ \\
\hline
\end{tabular}

As shown in Figure 1, the region around $0-10$ $\mathrm{Mb}$ has many QTL on the chromosome. Specifically, there are 56 QTL for five milk production traits, and seven QTL for other traits. In particular, 52 of these 56 milk production related QTL were clustered in a region of $\sim 3.6 \mathrm{Mb}$ (0.26-3.81 Mbp), including 15 QTL for fat $\%$ or fat content $[11,13,5,6,14,17,18,21,22,24], 13$ QTL for fat yield $[5,6,11,13,14,18,19,24,25,31], 10$ QTL for milk yield $[4,5,14,16,18,19,21,24], 10$ QTL for protein $\%$ or protein content $[5,6,14,18,24]$, and four QTL for protein yield [13, 18, 19, 24], respectively. Interestingly, this region of $\sim 3.6 \mathrm{Mb}$ on the assembly was expanded to a region of $\sim 30 \mathrm{cM}$ reported by different groups in the linkage map (Table 1). Therefore, our genome anchored QTL map significantly narrows the physical distance of QTL regions and perhaps provides the precise locations for identification of candidate genes. 


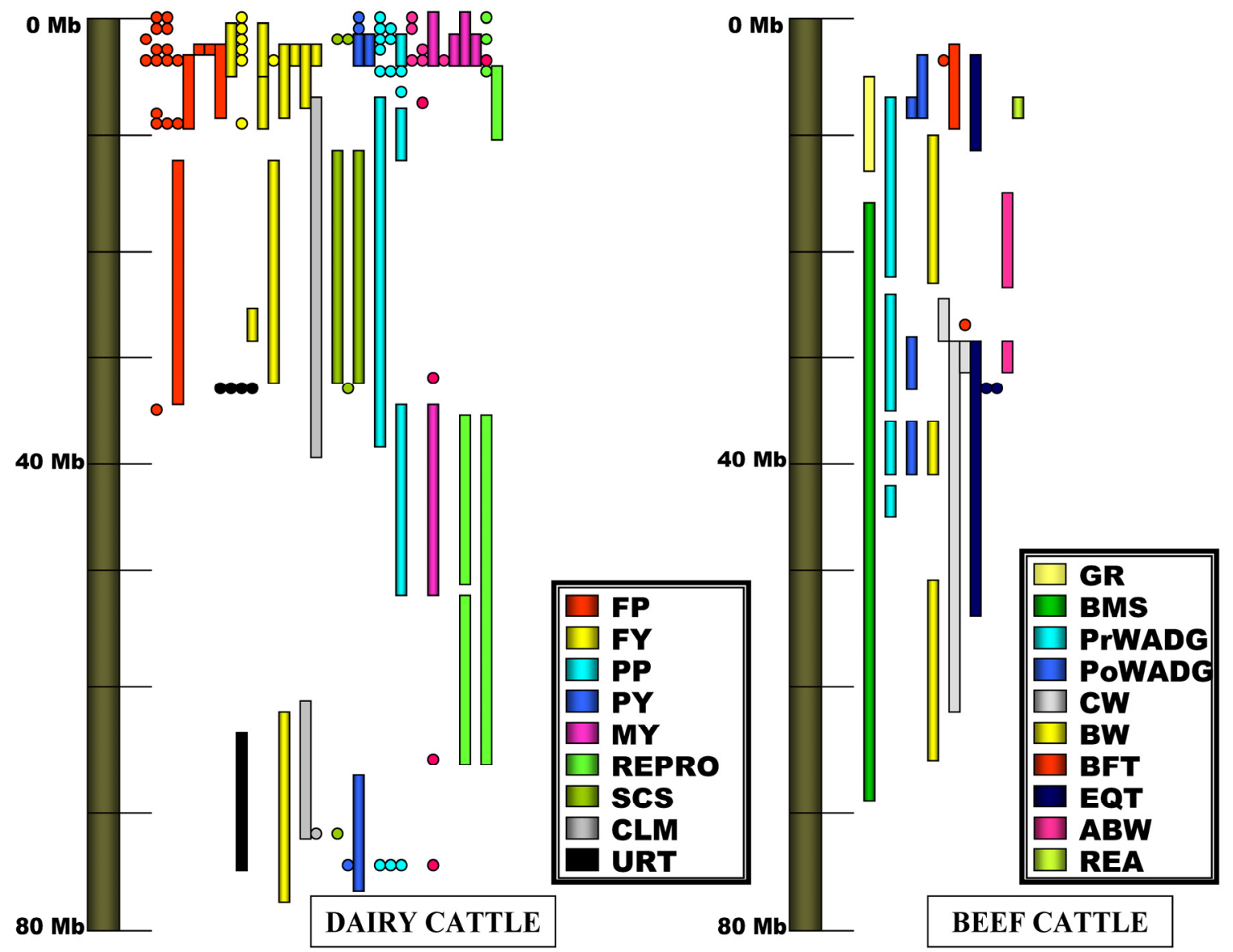

Figure 1. Genome assembly anchored QTL map of BTA14 (see Tables 1-3). The gray bar on the left represents the visualization of BTA14 from $0 \mathrm{Mb}$ to $80 \mathrm{Mb}$. Studies on dairy cattle are graphed on the left side with phenotypes represented by different colors, whereas studies in beef cattle are summarized on right side of the graph with phenotypes represented by different colors.

The high density of QTL for milk production traits in this small region of BTA14 has led to exploration of candidate genes in the region. In 2002, Grisart and colleagues [53] proposed that bovine diacylglycerol acyltransferase 1 (DGAT1) (at $0.44 \mathrm{Mb}$ ) is a promising candidate gene because a missense mutation (Lysine232Alanine) in the gene could explain the phenotypic variance in milk fat content and other milk characteristics. DGAT1 is a microsomal enzyme that utilizes diacylglycerol and fatty acyl CoA as substrates in order to catalyze the final stage of triacylglycerol synthesis [32]. Therefore, this gene should affect fat metabolism, including fat yield and percentage in the milk [33]. A knock-out study showed that both male and female Dgat $/$ - mice, even those fed a high fat diet, stabilized their weights and resisted fat storage [34], indicating the importance of DGAT1 in fat metabolism. Winter et al. [31] further found that the lysine variant was associated with higher milk fat content compared to its counterpart alanine variant in several cattle breeds.
Interestingly, Bennewitz and colleagues [14] observed a genome-wide significant conditional QTL effect on fat percentage at the proximal end of the chromosome and for protein percentage at a more distal chromosomal region in addition to the diallelic DGAT1 effects on milk, fat, and protein yield and fat and protein percentage. The authors argued that this conditional QTL effect might be caused by one or more additional alleles segregating at DGAT1 that were not previously detected, or by a second quantitative trait locus affecting these traits. Indeed, Kuhn et al. [17] reported strong evidence for segregation of at least three alleles in the promoter region of the DGAT1 gene that affects milk fat percentage. In the centromeric region of BTA14, cytochrome P450, family 11, subfamily $\mathrm{B}$ (CYP11B1) was also suggested to be the causative gene for the QTL related to fat metabolism [35]. The CYP11B1 gene was negatively associated with milk yield and protein yield, but positively associated with fat content [18]. 
Thirteen additional QTL for milk production traits were also identified outside this first $10 \mathrm{Mb}$ region on BTA14, including two at $33.62 \mathrm{Mb}$ and 11.78 $\mathrm{Mb}-33.62 \mathrm{Mb}$ for fat percentage or fat content $[4,6]$, two at $24.67 \mathrm{Mb}-27.34 \mathrm{Mb}$ and $61.48 \mathrm{Mb}-76.75 \mathrm{Mb}$ for fat yield $[11,16]$, three at $33.62 \mathrm{Mb}, 34.158 \mathrm{Mb}-51.17$ $\mathrm{Mb}$ and $65.03 \mathrm{Mb}$ for milk yield [4, 6, 23], five (one at $7.87 \mathrm{Mb}-39.55 \mathrm{Mb}$, one at $34.16 \mathrm{Mb}-51.17 \mathrm{Mb}$ and three at $73.84 \mathrm{Mb}$ ) for protein $\%$ [2, 20, 21, 23, 25] and one at $65.03 \mathrm{Mb}-75.88 \mathrm{Mb}$ for protein yield [11] (Figure 1 and Table 1). However, no candidate genes have been explored for these QTL on BTA14.

During the past several decades, the high intensity of selection for milk yield has led to a significant improvement in milk production, but it has also led to a decline in reproductive efficiency in dairy cattle. In the United States, Washburn and colleagues [36] re- ported that from 1976 to 1999 the average number of days open increased from 122 to 152 days for Jerseys and from 124 to 168 days for Holsteins. Services per conception also increased, from 1.91 to 2.94 services for both breeds during the same period. There are at least 6 QTL for reproductive traits detected on BTA14 (Figure 1 and Table 2). Calving ease QTL is located at 1.294 $\mathrm{Mb}$ [18], while both ovulation rate and twinning rate might share a common QTL region from $34.16 \mathrm{Mb}$ to $65.38 \mathrm{Mb}[26,27]$. However, it seems that three pregnancy related phenotypes have no common QTL locations: non-return rate is placed at $0.44 \mathrm{Mb}$ [18], pregnancy rate at $3.81 \mathrm{Mb}-11.78 \mathrm{Mb}$ [11], and daughter pregnancy rate (DPR) at $34.16 \mathrm{Mb}-51.17 \mathrm{Mb}$ [23] (Figure 1). Defining QTL ontology should be considered by the community in the future to search for common QTL for a given phenotype.

Table 2. QTL reported on BTA14 for health, reproduction and udder related traits in dairy cattle.

\begin{tabular}{|c|c|c|c|c|}
\hline Reference & P value & Markers & $\mathbf{M b}$ & $\mathbf{c M}$ \\
\hline \multicolumn{5}{|c|}{ CLINICAL MASTITIS (CLM) } \\
\hline Klungland et al. 2001 & & BM4513-BM6425 & $61.48-73.84$ & 79.79-95.14 \\
\hline Rupp et al. 2003 & $<0.01$ & BM6425 & 73.84 & 95.14 \\
\hline Viitala et al. 2003 & 0.01 & BMS1747-BMS740 & $7.86-39.55$ & $10.50-60.69$ \\
\hline \multicolumn{5}{|c|}{ REPRODUCTIVE TRAITS } \\
\hline Kaupe et al. 2007 for CE & $<0.05$ & CYP11B1 & 1.29 & 29.80 \\
\hline Schnabel et al. 2005 for DPR & & BMC1207-BMS1899 & $34.16-51.17$ & $51.94-69.01$ \\
\hline Kaupe et al. 2007 for NRR & $<0.05$ & DGAT1 & 0.44 & 18.70 \\
\hline Gonda et al. 2004 for OVR & 0.014 & BMS947-BM4305 & $51.27-65.03$ & 83.31 \\
\hline Ashwell et al. 2004 for PR & 0.01 & ILSTS011-CSSM066 & $3.81-11.78$ & $5.13-25.71$ \\
\hline Cobanoglu et al. 2005 for TWIN & 0.001 & BMC1207-BM2934 & $34.16-65.38$ & 51.94 \\
\hline \multicolumn{5}{|c|}{ SOMATIC CELL SCORE (SCS) } \\
\hline Ashwell et al. 1998 & 0.0096 & BM302 & 33.62 & 52.37 \\
\hline Kaupe et al. 2007 & $<0.001$ & CYP11B1 & 1.29 & 29.80 \\
\hline Kaupe et al. 2007 & $<0.05$ & CYP11B1 & 1.29 & 29.80 \\
\hline Rodriguez-Zas et al. 2002 & & BM6425 & 73.84 & 95.14 \\
\hline Rupp et al. 2003 & $<0.10$ & ILSTS011-BM302 & $11.78-33.62$ & 25.71-52.37 \\
\hline Zhang et al. 1998 & & ILSTS011-BM302 & $11.78-33.62$ & 25.71-52.37 \\
\hline \multicolumn{5}{|c|}{ UDDER RELATED TRAITS (URT) } \\
\hline Ashwell et al. 1997 for udder & 0.0052 & BM302 & 33.62 & 52.37 \\
\hline Ashwell et al. 1997 for USCS & 0.006 & BM302 & 33.62 & 52.37 \\
\hline Ashwell et al. 2002 for FUA & 0.0703 & BM302 & 33.62 & 52.37 \\
\hline Ashwell et al. 2002 for FTP & 0.04 & BM302 & 33.62 & 52.37 \\
\hline Schnabel et al. 2005 for RUW & 0.01 & BM4305-BL1036 & $65.03-76.75$ & 83.31-100.16 \\
\hline
\end{tabular}

Mastitis affects every dairy farm and up to $50 \%$ of all dairy cattle in the United States [37]. Economic losses are an estimated $\$ 180$ per cow per year or $\$ 2$ billion annually in the United States of America [38]. A total of 10 QTL for the disease were reported on BTA14, including three for clinical mastitis [25, 29, 30] and seven for somatic cell score (SCS) $[4,18,21,28,30]$. A region around $1.29 \mathrm{Mb}$ with $\mathrm{CYP11B} 1$ harbors a significant QTL for SCS, but two other regions, one at 7.86
$\mathrm{Mb}-39.55 \mathrm{Mb}$ and the other at $61.48 \mathrm{Mb}-73.84 \mathrm{Mb}$ might share QTL for both clinical mastitis and SCS. These data indicate that QTL information on SCS would help reduce incidence of clinical mastitis in dairy cattle. In addition, SCS has been widely used to indirectly measure udder traits in dairy cattle [39]. As shown in Figure 1 and Table 2, QTL for udder traits are also found in the same region as QTL for SCS, indi- 
cating that these traits are either controlled by the same gene or by genes in a linkage.

\section{QTL detected on BTA14 in beef cattle}

In beef cattle, QTL mapping has been mainly focused on growth traits, carcass and meat quality. The targeted phenotypes include hot carcass weight [7, 40], rib eye area (REA) $[8,41]$, average daily gain (ADG) [40, 42], intramuscular fat deposition (marbling) [9] and subcutaneous fat depth (backfat-EBV or fat thick- ness) $[9,8,43,44]$ (Table 3). Bos indicus (Brahman) and Bos taurus (Angus or Hereford) breeds have been heavily used in QTL mapping by Casas et al. [9], Kneeland et al. [42], Stone et al. [41] and Kim et al. [7]. Other commonly used breeds include: Wagyu [40], Belgian Blue [9] or composite breeds ( $1 / 2$ Red Angus, $1 / 4$ Tarentaise and $1 / 4$ Charolais) [8], or mixed breeds, such as $1 / 4$ Angus, $1 / 4$ Hereford, $1 / 4$ Red Poll and $1 / 4$ Pinzgauer cows with Piedmontese X Angus sire [44].

Table 3. QTL reported on BTA14 for growth, carcass, meat quality and eating quality traits in beef cattle.

\begin{tabular}{|c|c|c|c|c|}
\hline Reference & P value & Markers & $\mathbf{M b}$ & cM \\
\hline \multicolumn{5}{|c|}{ PRE-WEANNING AVERAGE DAILY GAIN (PrWADG) } \\
\hline Kneeland et al. 2004 & 0.046 & BMS1941-BMC1207 & 24.67-34.16 & $41.71-51.94$ \\
\hline Kneeland et al. 2004 & 0.041 & BM1577-BMS108 & $41.23-46.69$ & $63.16-67.67$ \\
\hline Kneeland et al. 2004 & 0.023 & BMC1207-BM1577 & $34.16-41.23$ & $51.94-63.16$ \\
\hline Mizoshita et al. 2004 & & BM1508-BMS1941 & $8.27-24.67$ & $17.85-41.71$ \\
\hline \multicolumn{5}{|c|}{ POST-WEANNING AVERAGE DAILY GAIN (PoWADG) } \\
\hline Kneeland et al. 2004 & 0.026 & BMS1747-TG & $7.66-7.87$ & $10.50-11.95$ \\
\hline Kneeland et al. 2004 & 0.025 & CSSM66-BMS1747 & $3.81-7.87$ & $5.13-10.50$ \\
\hline Kneeland et al. 2004 & 0.039 & BMC1207-BM1577 & $34.16-41.23$ & $51.94-63.16$ \\
\hline Mizoshita et al. 2004 & & BM8125-ILSTS008 & $27.34-32.08$ & $50.92-66.48$ \\
\hline \multicolumn{5}{|c|}{ BIRTH WEIGHT (BW) } \\
\hline Kneeland et al. 2004 & 0.031 & BMS1899-RM137 & $51.17-67.66$ & $69.01-85.18$ \\
\hline Kneeland et al. 2004 & 0.006 & BMS1678-BMS1941 & $9.19-24.67$ & $14.01-41.71$ \\
\hline Kneeland et al. 2004 & 0.049 & BMC1207-BM1577 & $34.16-41.23$ & $51.94-63.16$ \\
\hline \multicolumn{5}{|c|}{ CARCASS WEIGHT (CW) } \\
\hline Kim et al. 2003 & 0.611 & RM011-BM4513 & $27.20-61.48$ & $43.63-79.79$ \\
\hline Mizoshita et al. 2004 & 0.016 & BMS1941-INRA094 & $24.67-28.80$ & $41.71-49.83$ \\
\hline Mizoshita et al. 2004 & & BM8125-ILSTS008 & $27.34-32.08$ & $50.92-66.48$ \\
\hline \multicolumn{5}{|c|}{ BACKFAT THICKNESS (BFT) } \\
\hline Casas et al. 2000 & 0.47 & RM180-RM011 & $17.16-27.2$ & $35.31-43.63$ \\
\hline Casas et al. 2003 & 0.24 & ILSTS039-DIK5082 & $1.20-9.86$ & $0-21.30$ \\
\hline Moore et al. 2004 & 0.0058 & CSSM066 & 3.81 & 5.13 \\
\hline \multicolumn{5}{|c|}{ BEEF MARBLING SCORE (BMS) } \\
\hline Casas et al. 2003 & 0.45 & DIK2008-DIK4087 & $16.43-68.33$ & $31.26-86.63$ \\
\hline \multicolumn{5}{|c|}{ AVERAGE BODY WEIGHT (ABW) } \\
\hline Mizoshita et al. 2004 & & BM8125-ILSTS008 & $27.34-32.08$ & $50.92-66.48$ \\
\hline Mizoshita et al. 2004 & & MNB-14-BMS1941 & $16.97-24.67$ & $32.12-41.71$ \\
\hline \multicolumn{5}{|c|}{ EATING QUALITY TRAITS (EQT) } \\
\hline Casas et al. 2003 for CHOICE & 0.26 & ILSTS039-DIK4681 & $1.20-12.58$ & $0-25.71$ \\
\hline Guiterez-Zas et al. 2007 for $\mathrm{pH}$ & 0.0013 & RM011-PZ271 & $27.20-54.15$ & 43.63 \\
\hline Guiterez-Zas et al. 2007 for GBFI & 0.0084 & BM302 & 33.62 & 52.37 \\
\hline Guiterez-Zas et al. 2007 for GAFI & 0.0166 & ВМ302 & 33.62 & 52.37 \\
\hline \multicolumn{5}{|c|}{ GROWTH RATE (GR) } \\
\hline Miyata et al. 2004 & 0.05 & CSSM066-ILSTS011 & $3.81-11.78$ & $5.13-25.71$ \\
\hline \multicolumn{5}{|c|}{ RIB EYE AREA (REA) } \\
\hline Stone et al. 1999 & & DIK5377-DIK5082 & $8.54-9.86$ & $17.85-21.23$ \\
\hline
\end{tabular}

In contrast to the high number of QTL discovered in dairy cattle, the region between $0 \mathrm{Mb}-10 \mathrm{Mb}$ on BTA14 harbors only a few QTL for beef cattle traits, including two for post-weaning average daily gain
(PoWADG) [42], one for backfat thickness (BFT) [9, 43], one for \% USDA choice (CHOICE) [9] and one for average body weight (ABW) [40] (Figure 1 and Table 3). DGAT1, which is responsible for lipid metabolism 
traits in dairy cattle, was also tested in beef cattle. Unfortunately, Moore and colleagues [43] failed to observe any significant association of the DGAT1 polymorphism with backfat EBV. On the other hand, Barendse et al. [45] found that the TG gene, which is located at $7.658 \mathrm{Mb}$ on the chromosome, is significantly associated with marbling score in beef cattle. The association was further confirmed by the same group using another population of feedlot cattle [46]. In contrast, Moore and colleagues [43] failed to confirm the association of polymorphisms in the TG gene with any lipid metabolism traits (backfat EBV). Even so, Moore et al [43] did not exclude the possibility of other polymorphisms in DGAT1 or TG that might have a significant effect on backfat reported in other studies.

Broadly speaking, most QTL on BTA14 discovered in beef cattle fall into a region of $30 \mathrm{Mb}$, from 15 $\mathrm{Mb}$ to $45 \mathrm{Mb}$, including two QTL for PoWADG, four for pre-weaning average daily gain (PrWADG) [42], three for birth weight (BW) [42], three for carcass weight (CW) [7, 40], one for BFT [9], one for beef marbling score (BMS) [9] and two for ABW [40] (Figure 1 and Table 3). In addition, there is evidence that somewhere along these two regions on BTA14, there are also QTL for some eating quality traits (EQT) (24.67-46.69 Mbp): $\mathrm{pH}$ at 24h post-mortem and grilled beef flavor intensity (GBFI) bracketed by RM11-PZ271, and grilled abnormal flavor intensity (GAFI) bracketed by CSSM066-RM11 markers [3].

Since both DGAT1 and TG are located in the region of $0 \mathrm{Mb}-10 \mathrm{Mb}$ on BTA14, it is obvious that they cannot serve as candidate genes for QTL located in the region of $15 \mathrm{Mb}-45 \mathrm{Mb}$. Therefore, we targeted two candidate genes in the $15 \mathrm{Mb}-45 \mathrm{Mb}$ region: corticotrophin releasing hormone $(\mathrm{CRH})$ and fatty acid binding protein 4 (FABP4). The former is located at position $31.49 \mathrm{Mb}$, while the latter is positioned at $41.95 \mathrm{Mb}$ on the newly assembled bovine genome map. $\mathrm{CRH}$, which is a stress hormone, is released to the anterior pituitary to stimulate the secretion of adrenocorticotrophic hormone (ACTH), which upregulates cortisol. Cortisol has many significant metabolic effects that include stimulating gluconeogenesis in the liver, inhibiting glucose uptake in muscle and adipose tissue, and stimulating fat breakdown in adipose tissue [47]. In addition, transgenic mice with overexpression of $\mathrm{CRH}$ exhibit muscle wasting, decreased linear growth and obesity [48], whereas porcine CRH was reported to be significantly associated with backfat thickness, carcass length, average daily mass gain and REA [49]. Thus, $C R H$ is a good positional candidate gene for fat-related traits. Buchanan et al. 2005 [52] showed three SNPs that were associated with REA $(\mathrm{P}<0.034)$ and hot carcass mass $(\mathrm{P}<0.0015)$ in a Charolais-cross steer population. In 2007, Wibowo et al. [47] discovered a new SNP in the bovine CRH gene that is highly associated with backfat thickness $(\mathrm{P}<0.001)$ in a Wagyu $X$ Limousin $\mathrm{F}_{2}$ population.

FABP4, on the other hand, is a member of the fatty acid binding protein family that is thought to play a major role in the regulation of lipid and glucose homeostasis through its interaction with perioxisome proliferator-activated receptors (PPARs) [50]. In addition, FABP4 is also shown to interact with lipase, a primary enzyme involved in lipid catabolism, which regulates lipid hydrolysis and intracellular fatty acid trafficking [51]. Hence, FABP4 is a strong candidate gene for obesity as it is also located in the region of quantitative trait loci (QTL) for serum leptin levels in mice [54]. In 2006, Michal et al. [51] reported a significant association of FABP4 gene with marbling score and fat thickness in a Wagyu $X$ Limousin $F_{2}$ cross with P-values of 0.0246 and 0.0398 , respectively.

\section{Conclusion}

We reviewed more than 40 investigations related to identification of QTL for economically important traits on BTA14 in both dairy and beef cattle and anchored 126 QTL into the current bovine genome assembly. Such a process standardized the QTL locations by avoiding many conflicts reported on different linkage maps and linked the QTL to the functional gene regions. We believe that such an anchored QTL map further improves our ability to understand the genetic complexity of economically important traits located on BTA14 in both dairy and beef cattle.

\section{Acknowledgement}

This research was funded by an Emerging Research Issues Internal Competitive Grant from Washington State University, College of Agricultural, Human, and Natural Resource Sciences, Agricultural Research Center, Pullman, Washington State.

\section{Conflict of interests}

The authors have declared that no conflict of interest exists.

\section{References}

[1] Williams JL, Eggen A, Ferretti L et al. A bovine whole-genome radiation hybrid panel and outline map. Mamm Genome. 2002;13:469-474.

[2] Ashwell MS, Van Tassell CP, Sonstegard TS. A genome scan to identify quantitative trait loci affecting economically important traits in a US Holstein population. J Dairy Sci. 2001;84:2535-2542.

[3] Gutiérrez-Gil B, Wiener P, Nute GR et al. Detection of quantitative trait loci for meat quality traits in cattle. Anim Genet. 2008;39:51-61.

[4] Ashwell MS, Da Y, VanRaden PM, Rexroad CE Jr, Miller RH. Detection of putative loci affecting conformational type traits in 
an elite population of United States Holsteins using microsatellite markers. J Dairy Sci. 1998;81:1120-1125.

[5] Boichard D, Grohs C, Bourgeois F et al. Detection of genes influencing economic traits in three French dairy cattle breeds. Genet Sel Evol. 2003;35:77-101.

[6] Heyen DW, Weller JI, Ron M et al. A genome scan for QTL influencing milk production and health traits in dairy cattle. Physiol Genomics. 1999;1:165-175.

[7] Kim JJ, Farnir F, Savell J, Taylor JF. Detection of quantitative trait loci for growth and beef carcass fatness traits in a cross between Bos taurus (Angus) and Bos indicus (Brahman) cattle. J Anim Sci. 2003;81:1933-1942.

[8] MacNeil MD, Grosz MD. Genome-wide scans for QTL affecting carcass traits in Hereford $x$ composite double backcross populations. J Anim Sci. 2002;80:2316-2324.

[9] Casas E, Shackelford SD, Keele JW, Koohmaraie M, Smith TP, Stone RT. Detection of quantitative trait loci for growth and carcass composition in cattle. J Anim Sci. 2003;81:2976-2983.

[10] Marques E, de Givry S, Stothard P et al. A high resolution radiation hybrid map of bovine chromosome 14 identifies scaffold rearrangement in the latest bovine assembly. BMC Genomics. 2007;8:254.

[11] Ashwell MS, Heyen DW, Sonstegard TS et al. Detection of quantitative trait loci affecting milk production, health, and reproductive traits in Holstein cattle. J Dairy Sci. 2004;87:468-475.

[12] Bagnato A, Schiavini F, Rossoni A et al. Quantitative trait loci affecting milk yield and protein percentage in a three-country Brown Swiss population. J Dairy Sci. 2008;91:767-783.

[13] Bennewitz J, Reinsch N, Grohs C et al. Combined analysis of data from two granddaughter designs: A simple strategy for QTL confirmation and increasing experimental power in dairy cattle. Genet Sel Evol. 2003;35:319-338.

[14] Bennewitz J, Reinsch N, Paul S et al. The DGAT1 K232A mutation is not solely responsible for the milk production quantitative trait locus on the bovine chromosome 14. J Dairy Sci. 2004;87:431-442.

[15] Coppieters W, Riquet J, Arranz JJ et al. A QTL with major effect on milk yield and composition maps to bovine chromosome 14 . Mamm Genome. 1998;9:540-544.

[16] Harder B, Bennewitz J, Reinsch N et al. Mapping of quantitative trait loci for lactation persistency traits in German Holstein dairy cattle. J Anim Breed Genet. 2006;123:89-96.

[17] Kühn C, Thaller G, Winter A et al. Evidence for multiple alleles at the DGAT1 locus better explains a quantitative trait locus with major effect on milk fat content in cattle. Genetics. 2004;167:1873-1881.

[18] Kaupe B, Brandt H, Prinzenberg EM, Erhardt G. Joint analysis of the influence of CYP11B1 and DGAT1 genetic variation on milk production, somatic cell score, conformation, reproduction, and productive lifespan in German Holstein cattle. J Anim Sci. 2007;85:11-21.

[19] Looft C, Reinsch N, Karall-Albrecht C et al. A mammary gland EST showing linkage disequilibrium to a milk production QTL on bovine Chromosome 14. Mamm Genome. 2001;12:646-650.

[20] Mosig MO, Lipkin E, Khutoreskaya G, Tchourzyna E, Soller M, Friedmann A. A whole genome scan for quantitative trait loci affecting milk protein percentage in Israeli-Holstein cattle, by means of selective milk DNA pooling in a daughter design, using an adjusted false discovery rate criterion. Genetics. 2001;157:1683-1698.

[21] Rodriguez-Zas SL, Southey BR, Heyen DW, Lewin HA. Interval and composite interval mapping of somatic cell score, yield, and components of milk in dairy cattle. J Dairy Sci. 2002;85:3081-91.

[22] Ron M, Heyen DW, Weller JI et al. Detection and analysis of a locus affecting milk concentration in a US and Israeli dairy cattle population. Proc $6^{\text {th }}$ World Congr. Genet. Appl. Livest. Prod. 1998;26:422-425.
[23] Schnabel RD, Sonstegard TS, Taylor JF, Ashwell MS. Whole-genome scan to detect QTL for milk production, conformation, fertility and functional traits in two US Holstein families. Anim Genet. 2005;36:408-416.

[24] Thaller G, Krämer W, Winter A, Kaupe B, Erhardt G, Fries R. Effects of DGAT1 variants on milk production traits in German cattle breeds. J Anim Sci. 2003;81:1911-1918.

[25] Viitala SM, Schulman NF, de Koning DJ, Elo K, Kinos R, Virta A, Virta J, Mäki-Tanila A, Vilkki JH. Quantitative trait loci affecting milk production traits in Finnish Ayrshire dairy cattle. J Dairy Sci. 2003;86:1828-1836.

[26] Cobanoglu O, Berger PJ, Kirkpatrick BW. Genome screen for twinning rate QTL in four North American Holstein families. Anim Genet. 2005;36:303-308.

[27] Gonda MG, Arias JA, Shook GE, Kirkpatrick BW. Identification of an ovulation rate QTL in cattle on BTA14 using selective DNA pooling and interval mapping. Anim Genet. 2004;35:298-304.

[28] Ashwell MS, Da Y, Van Tassell CP, Vanraden PM, Miller RH, Rexroad CE Jr. Detection of putative loci affecting milk production and composition, health, and type traits in a United States Holstein population. J Dairy Sci. 1998;81(12):3309-3314.

[29] Klungland H, Sabry A, Heringstad B et al. Quantitative trait loci affecting clinical mastitis and somatic cell count in dairy cattle. Mamm Genome. 2001;12:837-842.

[30] Rupp R, Lagriffoul G, Astruc JM, Barillet F. Genetic parameters for milk somatic cell scores and relationships with production traits in French Lacaune dairy sheep. J Dairy Sci. 2003;86:1476-1481.

[31] Winter A, Krämer W, Werner FA et al. Association of a lysine-232/alanine polymorphism in a bovine gene encoding acyl-CoA:diacylglycerol acyltransferase (DGAT1) with variation at a quantitative trait locus for milk fat content. Proc Natl Acad Sci U S A. 2002;99:9300-9305.

[32] Cases S, Smith SJ, Zheng YW et al. Identification of a gene encoding an acyl CoA:diacylglycerol acyltransferase, a key enzyme in triacylglycerol synthesis. Proc Natl Acad Sci U S A. 1998;95:13018-13023.

[33] Cases S, Stone SJ, Zhou P et al. Cloning of DGAT2, a second mammalian diacylglycerol acyltransferase, and related family members. J Biol Chem. 2001;276:38870-38876.

[34] Smith SJ, Cases S, Jensen DR et al. Obesity resistance and multiple mechanisms of triglyceride synthesis in mice lacking Dgat. Nat Genet. 2000;25:87-90.

[35] de Roos AP, Schrooten C, Mullaart E, Calus MP, Veerkamp RF. Breeding value estimation for fat percentage using dense markers on Bos taurus autosome 14. J Dairy Sci. 2007;90:4821-4829.

[36] Washburn SP, Silvia WJ, Brown CH, McDaniel BT, McAllister AJ. Trends in reproductive performance in Southeastern Holstein and Jersey DHI herds. J Dairy Sci. 2002;85:244-251.

[37] Owen JB, Axford RF, Bishop SC. Mastitis in dairy cattle. In: Axford RF, Bishop SC, Nicholas FW, Owen JB, ed. Breeding for disease resistance in farm animals. Wallingord: $\mathrm{CAB}$ International. 2000:243-52.

[38] Nash DL, Rogers GW, Cooper JB, Hargrove GL, Keown JF, Hansen LB. Heritability of clinical mastitis incidence and relationships with sire transmitting abilities for somatic cell score, udder type traits, productive life, and protein yield. J Dairy Sci. 2000;83:2350-2360.

[39] Pösö J, Mäntysaari EA. Relationships between clinical mastitis, somatic cell score, and production for the first three lactations of Finnish Ayrshire. J Dairy Sci. 1996;79:1284-1291.

[40] Mizoshita K, Watanabe T, Hayashi H et al. Quantitative trait loci analysis for growth and carcass traits in a half-sib family of purebred Japanese Black (Wagyu) cattle. J Anim Sci. 2004;82:3415-3420.

[41] Stone RT, Keele JW, Shackelford SD, Kappes SM, Koohmaraie $\mathrm{M}$. A primary screen of the bovine genome for quantitative trait 
loci affecting carcass and growth traits. J Anim Sci. 1999;77:1379-1384.

[42] Kneeland J, Li C, Basarab J et al. Identification and fine mapping of quantitative trait loci for growth traits on bovine chromosomes 2, 6, 14, 19, 21, and 23 within one commercial line of Bos taurus. J Anim Sci. 2004;82:3405-3414.

[43] Moore SS, Li C, Basarab J et al. Fine mapping of quantitative trait loci and assessment of positional candidate genes for backfat on bovine chromosome 14 in a commercial line of Bos taurus. J Anim Sci. 2003;81:1919-1925.

[44] Casas E, Shackelford SD, Keele JW, Stone RT, Kappes SM, Koohmaraie M. Quantitative trait loci affecting growth and carcass composition of cattle segregating alternate forms of myostatin. J Anim Sci. 2000;78:560-569.

[45] Barendse WJ. Assessing lipid metabolism - International patent application number PCT/AU98/00882. International publication No WO 99/23248. 1999.

[46] Wood IA, Moser G, Burrell DL, Mengersen KL, Hetzel DJ. A meta-analytic assessment of a thyroglobulin marker for marbling in beef cattle. Genet Sel Evol. 2006;38:479-494.

[47] Wibowo TA, Michal JJ, Jiang Z. Corticotropin releasing hormone is a promising candidate gene for marbling and subcutaneous fat depth in beef cattle. Genome. 2007;50:939-945.

[48] Stenzel-Poore MP, Cameron VA, Vaughan J, Sawchenko PE, Vale W. Development of Cushing's syndrome in corticotropin-releasing factor transgenic mice. Endocrinology. 1992;130:3378-3386.

[49] Muráni E, Murániová M, Ponsuksili S, Schellander K, Wimmers K. Molecular characterization and evidencing of the porcine $\mathrm{CRH}$ gene as a functional-positional candidate for growth and body composition. Biochem Biophys Res Commun. 2006;342:394-405.

[50] Damcott CM, Feingold E, Moffett SP et al. Genetic variation in uncoupling protein 3 is associated with dietary intake and body composition in females. Metabolism. 2004;53:458-464.

[51] Michal JJ, Zhang ZW, Gaskins CT, Jiang Z. The bovine fatty acid binding protein 4 gene is significantly associated with marbling and subcutaneous fat depth in Wagyu x Limousin F2 crosses. Anim Genet. 2006;37:400-402.

[52] Buchanan FC, Thue TD, Yu P, Winkelman-Sim DC. Single nucleotide polymorphisms in the corticotrophin-releasing hormone and pro-opiomelancortin genes are associated with growth and carcass yield in beef cattle. Anim Genet. 2005;36:127-131.

[53] Grisart B, Coppieters W, Farnir F et al. Positional candidate cloning of a QTL in dairy cattle: identification of a missense mutation in the bovine DGAT1 gene with major effect on milk yield and composition. Genome Res. 2002;12:222-231.

[54] Ogino T, Moralejo DH, Kose H, Yamada T, Matsumoto K. Serum leptin concentration is linked to chromosomes 2 and 6 in the OLETF rat, an animal model of type 2 diabetes with mild obesity. Mamm Genome. 2003;14:839-444.

[55] Miyata M, Gasparin G, Coutinho LL et al. Quantitative trait loci (QTL) mapping for growth traits on bovine chromosome 14 . Genet Mol Biol. 2007;30:364-369.

[56] Spelman RJ, Ford CA, McElhinney P, Gregory GC, Snell RG. Characterization of the DGAT1 gene in the New Zealand dairy population. J Dairy Sci. 2002;85:3514-3417. 